\title{
Unmanned Aerial System-Based Multispectral Water Quality Monitoring in the Iberian Pyrite Belt (SW Spain)
}

\author{
Melisa A. Isgró ${ }^{1,2}$ (D) M. Dolores Basallote ${ }^{2}$ (D) Luis Barbero $^{1}$ (D)
}

Received: 31 March 2021 / Accepted: 6 November 2021 / Published online: 23 November 2021

(c) The Author(s) 2021

\begin{abstract}
Few studies have assessed mining-associated water pollution using spectral characteristics. We used high-resolution multispectral data acquired by unmanned aerial drones combined with in situ chemical data to assess water quality parameters in 12 relatively small water bodies located in the Tharsis complex, an abandoned mining area in the Iberian pyrite belt (SW Spain). The spectral bands of Micasense RedEdge-MX Dual and spectral band combinations were used jointly with physicochemical data to estimate water quality parameters and develop reliable empirical models using regression analysis. Physicochemical parameters including pH, ORP, EC, Al, Cu, Fe, Mn, S, Si, and Zn were estimated with high accuracy levels $\left(0.81<\mathrm{R}^{2}<0.99,4<\mathrm{RMSE} \%<75,0.01<\mathrm{MAPE}<0.97\right)$. In contrast, the observed and modelled values for $\mathrm{Ba}, \mathrm{Ca}$, and Mg did not agree well $\left(0.42<\mathrm{R}^{2}<0.70\right)$. The best-fitted models were used to generate spatial distribution maps, providing information on water quality patterns. This study demonstrated that using empirical models to generate spatial distribution maps can be an effective and easy way to monitor acid mine drainage.
\end{abstract}

Keywords Acid mine drainage $\cdot$ Abandoned mine $\cdot$ Water monitoring $\cdot$ Drone $\cdot$ Low altitude remote sensing, multispectral sensor

\section{Introduction}

Metalliferous mining has left a severe environmental legacy of numerous abandoned mining districts containing metalrich wastes that remain as long-term sources of acidic and metal-polluted water known as (Nieto et al. 2007; Runkel et al. 2012; Yang et al. 2020). Indeed, acid mine drainage (AMD) is the main environmental pollution problem associated with coal and metal-bearing mineral mining and it is of international concern (Acharya and Kharel 2020; Qian and Li 2019). Thus, it is imperative to develop cost-effective, efficient, and reliable monitoring tools that can be used by

Melisa A. Isgró

meli.isgro@gmail.com

M. Dolores Basallote maria.basallote@dct.uhu.es

Luis Barbero

luis.barbero@uca.es

1 Department of Earth Sciences, University of Cádiz, Av. República Saharaui s/n, Puerto Real, 11510 Cádiz, Spain

2 Department of Earth Sciences, University of Huelva, Campus El Carmen s/n, 21071 Huelva, Spain environmental agencies and companies in charge of mining concessions.

Traditional procedures for water quality monitoring in reservoirs involve in-situ measurements, sampling, and laboratory analysis (Sagan et al. 2020). Remote sensing provides a powerful alternative tool that is less time-consuming and provides spatial and temporal information to monitor water quality changes. Several authors have successfully retrieved many water quality parameters by remote sensing, with the most commonly measured variables being total dissolved solids, chlorophyll- $a$, turbidity, Secchi disk depth, and colored dissolved organic matter (Abdelmalik 2018; Chawla et al. 2020; Japitana and Burce 2019; Zhu et al. 2011;). Most of them have been based on satellite datasets (Barrett and Frazier 2016; Bonansea et al. 2015; Hansen et al. 2015; Philipson et al. 2016), and most recently, unmanned aerial systems (UAS) platforms have been also tested for this purpose (Arango and Nairn 2020; Castro et al. 2020; Olivetti et al. 2020; Su and Chou 2015).

Nonetheless, spectral characteristics has rarely been used to report water quality status in mining areas (Buzzi et al. 2014; Davies and Calvin 2017; Flores et al. 2021; Gläßer et al. 2011; Modiegi et al. 2020; Pyankov et al. 2021; Riaza 
et al. 2012; Swayze et al. 2000; Tesfamichael and Ndlovu 2018; Williams et al. 2002). Water bodies associated with AMD have a complex composition that requires quantifying a wide range of parameters and few studies have addressed this issue by applying quantitative modeling of hydrochemical concentrations (Modiegi et al. 2020; Tesfamichael and Ndlovu 2018). Most recently, UAS-based hyperspectral data have been used to monitor acidic water, generating highresolution hydrogeochemical maps, proving it to be possible (Flores et al. 2021). Indeed, UAS is becoming increasingly popular in environmental monitoring due to the acquisition flexibility, the high spatial and temporal resolution achieved, and the possibility to acquire data unaffected by cloud cover.

In this context, we decided to calibrate empirical models through regression analysis to predict water quality parameters using in situ physicochemical parameters and spectral reflectance values obtained by the commercial Micasense RedEdge-MX Dual sensor. The Iberian pyrite belt (IPB), which hosts one of the largest concentrations of massive sulfide on Earth (Leistel et al. 1997), and is well-known for its extensive AMD environmental impacts (Cánovas et al. 2016; Galván et al. 2016; Grande et al. 2014; Nieto et al. 2007; Olías et al. 2019, 2021; Sánchez España et al. 2005), was selected as the study area. The different compositions of the numerous acid drainages affects the color of the water, making the IPB an ideal scenario for testing water quality monitoring techniques using remote sensing (Riaza et al. 2014; Sanchez España 2008). This work is intended to implement an easily reproducible tool, which can be used to monitor water bodies with different complex compositions in mine-affected zones. Nevertheless, it is important to highlight that this is an auxiliary tool for monitoring the acid drainage generation process, and does not replace conventional environmental monitoring.

\section{Methods}

The methodology applied in this study is summarized in Fig. 1. Three flight campaigns were carried out during July and October 2020 with the Micasense RedEdge-MX Dual sensor onboard a UAS over the sampling sites. Concurrently with flights, in situ physicochemical data acquisition was performed in each waterbody. Afterwards, statistical analysis was used to get the best-fitted model for each water quality parameter.

\section{Sampling Sites}

The area of research involved two abandoned mining sites located in the Tharsis complex, in the IPB: Tharsis Mine (Fig. 2A) and Lagunazo Mine (Fig. 2B). Mining activity in the IPB dates to the Tartessians in prehistoric times,

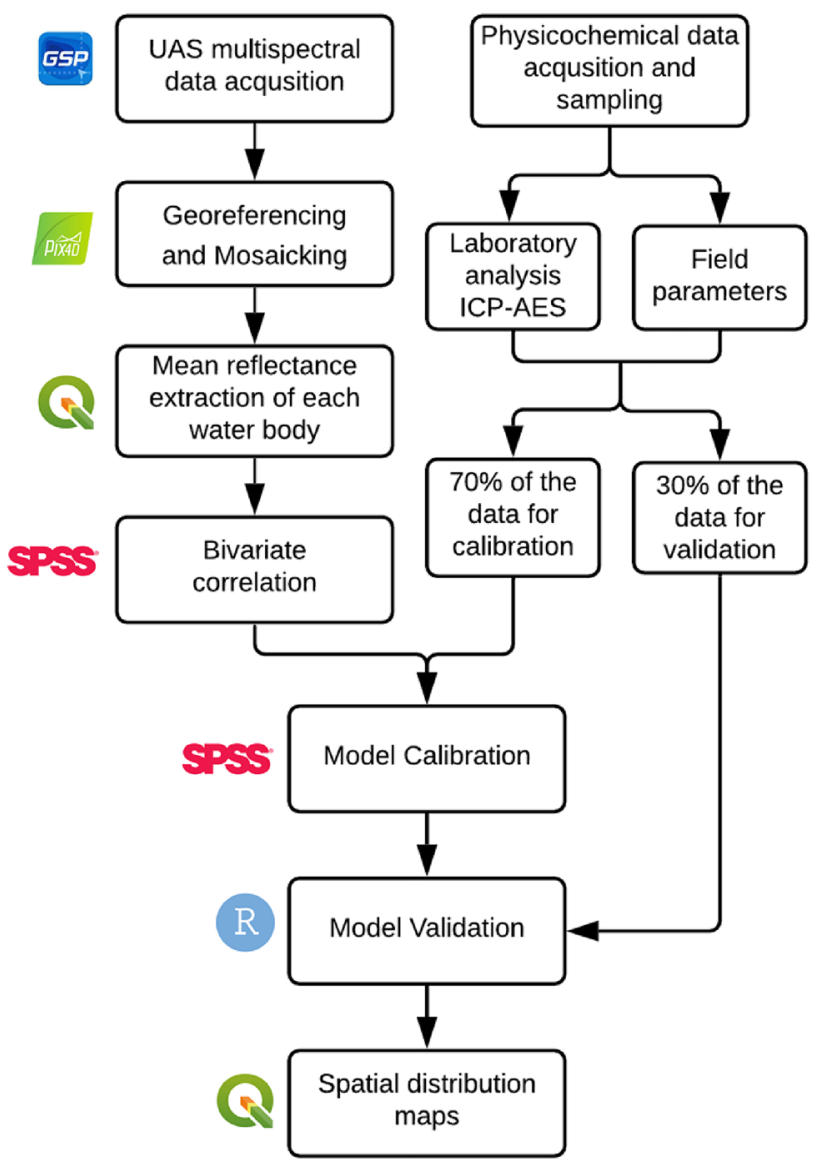

Fig. 1 Flowchart of the applied methodology

which has left a legacy of several abandoned sites, most of them closed without any environmental guidelines, mine closure, or control plans to protect the environment (Grande et al. 2014). As a result, numerous open mine pits and water bodies contain acidic water due to the dumped debris that continues to oxidize.

For this study, 12 different water bodies containing acid and non-acid waters were considered. At the Tharsis mine site (Fig. 2A), seven water bodies were sampled; four pit lakes flooded with acidic waters [Filón Norte (FN), Filón Sur (FS), Filón Centro (FC), and Sierra Bullones (SB)], a clean water reservoir used for agricultural purposes (Embalse Grande (EG)), acid leachate water flowing through a sulfide spoil heap (Th18), and a moderately acidified municipal reservoir (Embalse del Pino (EP)). In the Lagunazo mining area (Fig. 2B), five water bodies were sampled: a pit lake (Mina Lagunazo (ML)), a clean water dam (Embalse Lagunazo (EL)), and three surficial AMD sites, where water flows through a waste dump and pyrite-rich waste materials (Laguna Lagunazo (LLA, LLB, and LLC). 


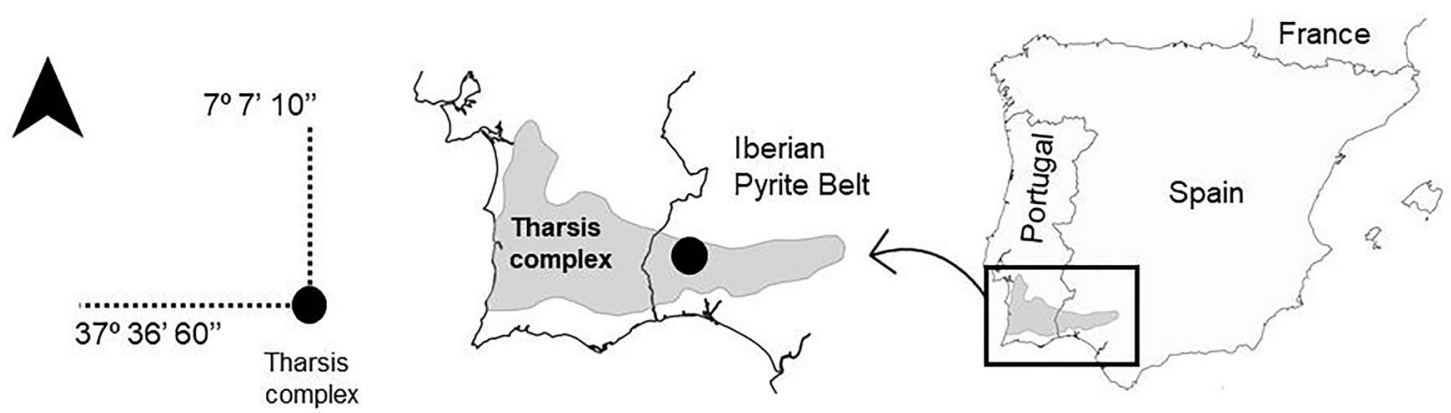

(A) Tharsis mine

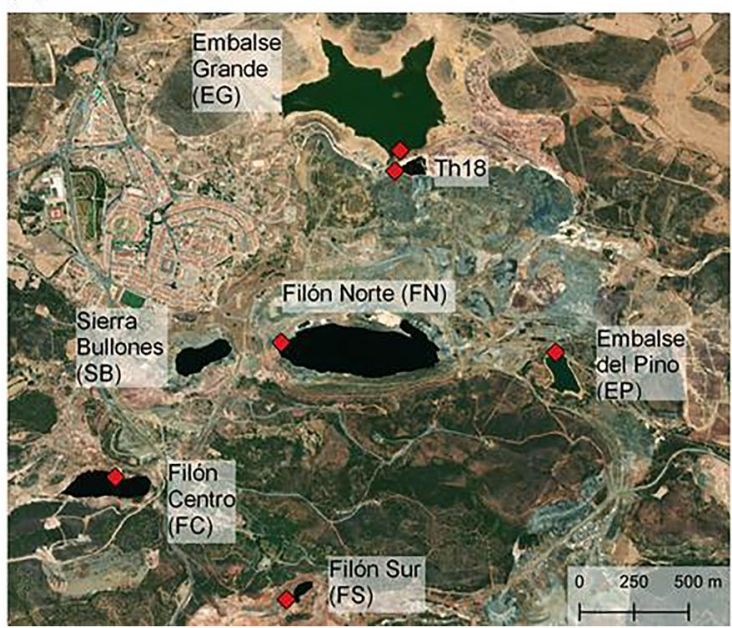

Fig. 2 Location map of the sampling sites. Seven water bodies [Filón Norte (FN), Filón Sur (FS), Filón Centro (FC), Sierra Bullones (SB), Embalse Grande (EG), Th18, and Embalse del Pino (EP)) sampled in the Tharsis Mine (A), and five water bodies (Mina Lagunazo (ML),

\section{Water Quality Data Collection}

The exact locations for water samples collection are shown in Fig. 2 and supplemental Table S-1 (Online Resource, $\mathrm{OR})$. Field physicochemical parameters such as $\mathrm{pH}$, electrical conductivity (EC), oxidation-reduction potential (ORP), and temperature were measured at each sampling point with a CrisonMM40 p multimeter (Fig. 3E), previously calibrated with certified solutions. Turbidity was measured using a Hanna HI-93703 portable turbidity meter at the water surface in all of the studied water bodies. Water samples were collected in high-density polyethylene (HDPE) bottles previously washed with a solution of $10 \% \mathrm{HNO}_{3}$, filtered immediately after sampling through a $0.45 \mathrm{~mm}$ pore size cellulose nitrate membrane, and acidified to $\mathrm{pH}<2$ with $\mathrm{HNO}_{3}$. The samples were analyzed by inductively coupled plasma-atomic emission spectroscopy (ICP-AES; PerkinElmer ${ }^{\circledR}$ Optima $3200 \mathrm{RL}$ ) for major elements (Al, Ba, Ca, $\mathrm{Cu}, \mathrm{Fe}, \mathrm{K}, \mathrm{Mg}, \mathrm{Mn}, \mathrm{Na}, \mathrm{P}, \mathrm{S}, \mathrm{Si}, \mathrm{Sr}$, and $\mathrm{Zn}$ ) at the Institute of Environment Assessment and Water Research (IDAEACSIC, Barcelona). Detection limits were: $0.5 \mathrm{mg} \mathrm{L}^{-1}$ for
(B) Lagunazo mine

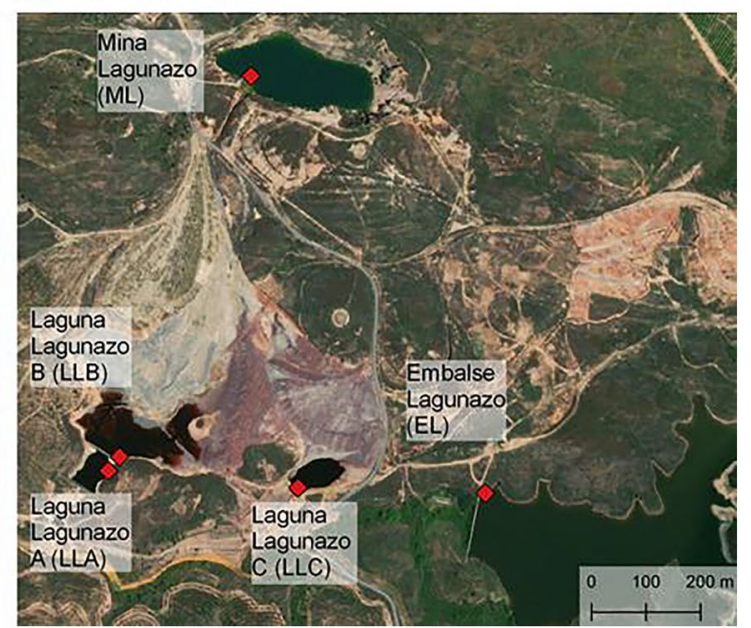

Embalse Lagunazo (EL), Laguna Lagunazo A, B, and (LLA, LLB, and LLC, respectively)] in Lagunazo Mine site (B). Red diamonds indicate the water samples collection

$\mathrm{K}$ and $\mathrm{Na} ; 0.2 \mathrm{mg} \mathrm{L}^{-1}$ for $\mathrm{Al}, \mathrm{Ca}, \mathrm{Cu}, \mathrm{Fe}, \mathrm{Mg}, \mathrm{P}, \mathrm{S}, \mathrm{Si}$, and $\mathrm{Zn}$; and $0.005 \mathrm{mg} \mathrm{L}^{-1}$ for $\mathrm{Ba}, \mathrm{Mn}$, and $\mathrm{Sr}$. The analytical precision error was estimated to be $\approx 7 \%$. Certified solutions (CPI International-CCV standard 1-solution A) and two AMD laboratory standards supplied by P. Verplank (USGS) were intercalated within the samples to check the analytical accuracy. The deviation from the recommended values was always less than 5\%. Sierra Bullones was not water sampled due to its inaccessibility. However, as it is connected underground to Filón Norte, and their chemical properties have been shown to be similar (González et al. 2018), they were considered the same for this study.

\section{Multispectral Imagery Data Collection and Processing}

The sensor employed to acquire the multispectral images was the Micasense RedEdge-MX Dual Camera (MicaSense, Inc., USA, http://www.micasense.com/) onboard a DJI Matrice 210 V2 RTK (Fig. 3C). The sensor has 10 bands running from visible through the near-infrared spectrum, 
Fig. 3 Photographs of the zone: Filón Sur (A), Embalse del Pino (B), DJI Matrice 210 V2 RTK with the sensor Micasense RedEdge-MX Dual Camera (C), MicaSense's Calibrated Reflectance Panel (CRP) (D), CrisonMM40 p multimeter (E)
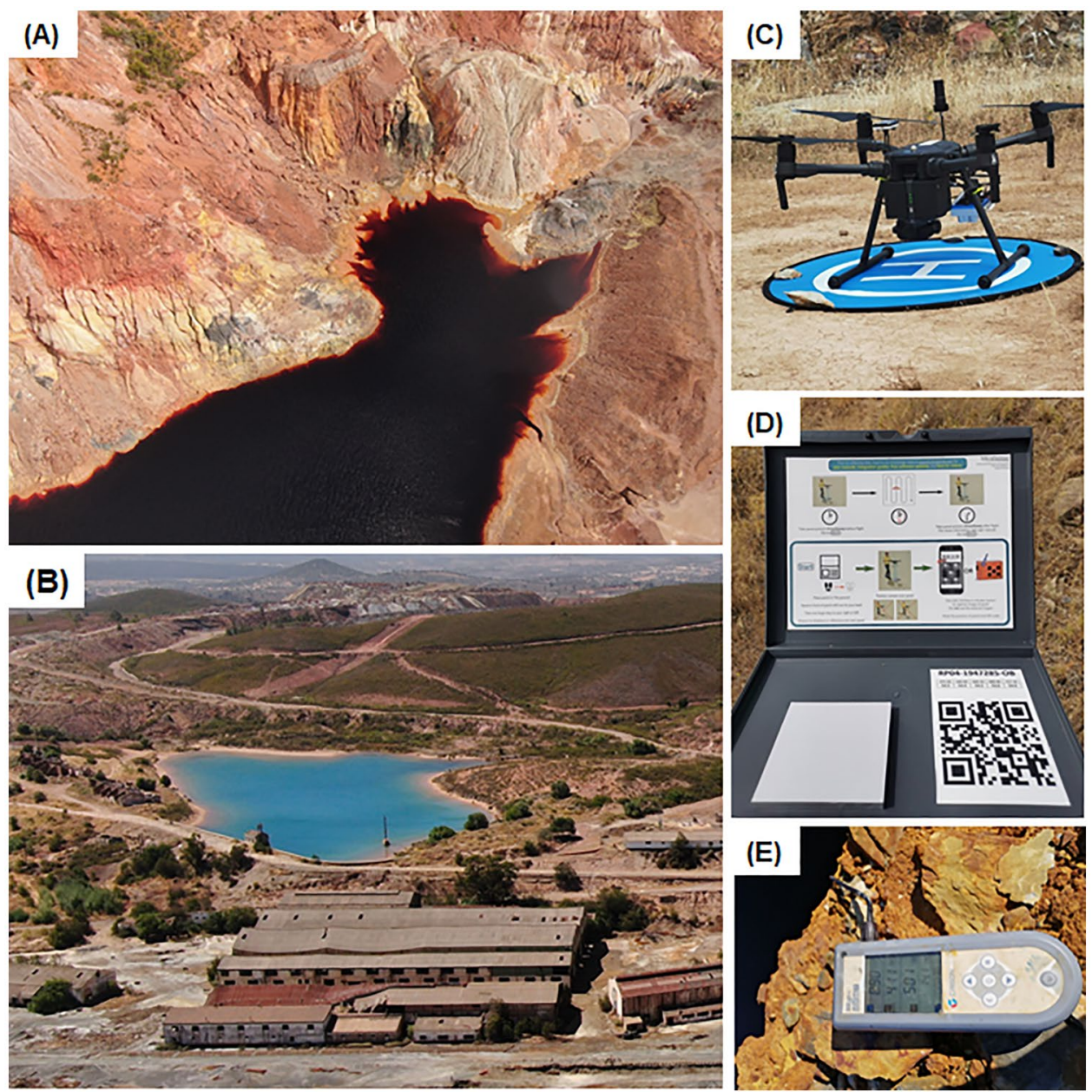

capable of obtaining information in the coastal blue $444 \mathrm{~nm}$ (28), blue $475 \mathrm{~nm}$ (32), green $531 \mathrm{~nm}$ (14), green $560 \mathrm{~nm}$ (27), red $650 \mathrm{~nm}$ (16), red $668 \mathrm{~nm}(14)$, red edge $705 \mathrm{~nm}$ (10), red edge $717 \mathrm{~nm}$ (12), red edge $740 \mathrm{~nm}$ (18), and NIR $842 \mathrm{~nm}$ (57). Micasense RedEdge-MX Dual is a lightweight camera of $508.8 \mathrm{~g}$ with a ground sample distance (GSD) of $8 \mathrm{~cm}$ at the selected flight altitude of $120 \mathrm{~m}$, a capture rate of 1 capture per second of 12-bit RAW, and a 47.2 field of view (FOV) for the ten bands. The sensor resolution is 1.2-megapixel for each of the multispectral bands and 3.2-megapixel for the RGB captures. It is equipped with a GPS, a downwelling light sensor (DLS 2), and MicaSense's calibrated reflectance panel (CRP; Fig. 3D). It also features a global shutter on the 10 lenses to avoid issues related to the movement of the UAS during the flight. While the GPS is used for georeferencing, the last two (DLS 2 and CRP) are necessary for the radiometric calibration on the ambient light changes during the flight. For this purpose, a picture of the CRP was taken before and after the flight to capture the lighting conditions. The UAS flights were performed using the DJI GS Pro planning software, which ensured the autonomous take-off, flight, and landing of the UAS.
The water bodies sampled on July 7th were SB, FN, FS, and EP (Fig. 2, OR Table S-1). On July 8th, the flight was performed over EG and Th18. Finally, on the 7th of October, the water bodies located in the Lagunazo area (EL, ML, LLA, LLB, LLC) were overflown, and three water bodies located in the Tharsis complex (FN, SB, and EG) were repeated to verify the results obtained in the previous campaign. For all the missions, the height was set at $120 \mathrm{~m}$ AGL (above ground level) altitude to ensure a ground sample distance (GSD) of $8 \mathrm{~cm} /$ pixel, the overlapping was set at $80 \%$ frontal and $75 \%$ side image overlap, the grid was simple, and the speed was set at $10 \mathrm{~m} \mathrm{~s}^{-1}$. It is assumed that all of the multispectral imagery was in the nadir position due to the location of the camera. No ground control points (GCPs) were added to the flights since the Micasense sensor has an integrated GPS that geo-tagged each of the images acquired by the UAS.

Pix4D mapper (Pix4D S.A., Lucerne, Switzerland, https://www.pix4d.com/) was the Structure from Motion $(\mathrm{S} f \mathrm{M})$ software used to process the multispectral images. This software performs the radiometric processing and calibration using the parameters written in the EXIF metadata 
and related to the camera, as well as the CRP to calculate the absolute irradiance and the DLS data for normalizing each image for changes in the incoming radiation during the flight. The final products of the process are 10 single reflectance calibrated GEOTIFFs. These maps contained reflectance values ranging between 0.0 and 1.0 for each pixel. Atmospheric correction was not considered for the UAS imagery, since it is a close-range remote sensing approach and the atmosphere layer between the UAS and the ground is so thin that it can be ignored (Castro et al. 2020).

\section{Reflectance Extraction}

To perform the extraction of the spectral signature of each of the water bodies from the multispectral imagery, the centroid of the water body shape was extracted and the mean reflectance value of all the pixel values included in a circular buffer of $3 \mathrm{~m}$ around each centroid point was estimated using the QGIS 3.10.7 Zonal Statistics Plugin. The centroid was set as a location that assures the absence of aquatic vegetation and avoids shallow waters since the chlorophyll and the bottom substrate may affect the water spectra (Zeng et al. 2017). The buffer was set to consider the variability of pixel values due to the heterogeneous nature of water affected by environmental variables such as sunglint, waves, and particles in the water.

\section{Model Calibration and Validation}

The collected data were divided into two subsets, the model calibration $(70 \%)$ and validation $(30 \%)$ datasets, to ensure a wide range of the physicochemical variables to obtain a model as robust as possible. The waterbodies flights from July (EP) and October (FC, FN, EG, EL, ML, SB, LLA, and LLB) were used for the model calibration, while the validation dataset comprised the Th18, EG, and FS flights from July and LLC from October.

Many authors have found a better relationship between transformed chemical parameters and spectral satellite data (Bonansea et al. 2015; Brezonik et al. 2005; Sriwongsitanon et al. 2011), so the chemical parameters were ln-transformed to assess possible stronger correlation to the spectral data. To determine which spectral bands and spectral band combinations (SBCs) were the best predictor for each chemical parameter, a correlation analysis was carried out between the raw and the ln-transformed chemical data vs. the mean reflectance values of the 10 spectral bands and the tested SBCs, which are either an index or a ratio (Bonansea et al. 2015). The Shapiro-Wilks' test ( $p>0.05)$ was used to test for normality in the raw and ln-transformed parameters. Only normal distributed data were used in this study and correlations based on bivariate analysis were tested using Pearson-r.
Table 1 List of spectral band combinations (SBCs) tested in this study

\begin{tabular}{lll}
\hline Algorithm & Band math & References \\
\hline A1 (NDVI) & (NIR-R650)/(NIR + R650) & Rouse and Space (1978) \\
A2 (NDWI) & $(\mathrm{g} 560-\mathrm{NIR}) /(\mathrm{g} 560+\mathrm{NIR})$ & McFeeters (1996) \\
A3 & r650/re705 & Simple ratio \\
A4 & re705/nir & Simple ratio \\
A5 & $(\mathrm{g} 531 / \mathrm{g} 560) * \mathrm{r} 650$ & Three-band algorithm \\
A6 & $($ re705/re717)*r668 & Three-band algorithm \\
A7 & $(\mathrm{g} 560 * \mathrm{~g} 531) / \mathrm{b} 475$ & Three-band algorithm \\
A8 & $(\mathrm{g} 560-\mathrm{g} 531) / \mathrm{b} 475$ & Three-band algorithm \\
A9 & $(\mathrm{g} 560 / \mathrm{g} 531) * \mathrm{~b} 475$ & Three-band algorithm \\
A10 & $(\mathrm{re} 705 / \mathrm{r} 650) * \mathrm{~g} 531$ & Three-band algorithm \\
\hline
\end{tabular}

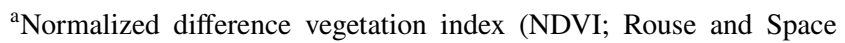
1978)

bNormalized difference water index (NDWI; McFeeters 1996)

Using the model calibration dataset, empirical models were constructed relating the mean reflectance values of the significant bands and/or the SBCs as the predictable variable with the chemical data and $\ln$-transformed chemical data as the dependent variable. A total of 17 water quality parameters $(\mathrm{pH}, \mathrm{ORP}$, $\mathrm{EC}, \mathrm{Al}, \mathrm{Ba}, \mathrm{Ca}, \mathrm{Cu}, \mathrm{Fe}, \mathrm{K}, \mathrm{Mg}, \mathrm{Mg}, \mathrm{Na}, \mathrm{P}, \mathrm{S}, \mathrm{Si}, \mathrm{Sr}$, and $\mathrm{Zn}$ ), the 10 sensor's spectral bands, and 10 SBCs (Table 1) were considered in this study. To ensure reliable models, SLR and MLR were tested using a stepwise selection method.

The two best-performing models per chemical parameter were chosen statistically according to five factors, the: coefficient of determination $\left(\mathrm{R}^{2}\right)$, adjusted coefficient of determination $\left(\operatorname{Adj}^{2}\right)$, standard error of estimation (SEE), Akaike information criterion (AIC), and significance (p) value (Abdelmalik 2018). All of the correlation and regression analyses were performed using the IBM SPSS statistics (IBM 2020).

Once the two best fits for each chemical parameter were determined, the prediction quality of the models was assessed using the validation dataset. The performance metric statistics calculated were: root mean square error (RMSE, Eq. 1), normalized root mean square error (RMSE\%, Eq. 2), mean absolute percentage error (MAPE, Eq. 3, 4), and bias (Eq. 4) (Castro et al. 2020).

$$
\begin{aligned}
& R M S E=\sqrt{\frac{\sum_{i=1}^{n}\left(M_{i}-O_{i}\right)^{2}}{n}} \\
& R M S E \%=100 \frac{R M S E}{\frac{1}{n} \sum_{i=1}^{n} O_{i}}
\end{aligned}
$$




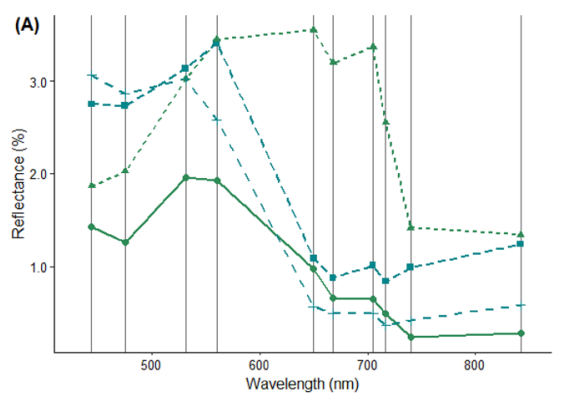

Fig. 4 Spectral signature of the sampled water bodies. A EG and EL are non-acid waters, EP and ML are greenish-blue acid waters. B FC, FN, FS, TH18, SB, LLA, LLB, and LLC are dark reddish-brown acid

MAPE $=\frac{\sum_{i=1}^{n} \frac{\left|M_{i}-O_{i}\right|}{O_{i}}}{n}$

bias $=\frac{\sum_{i=1}^{n}\left(M_{i}-O_{i}\right)}{n}$

where $\mathrm{M}$ is the modeled value, $\mathrm{O}$ is the observed value, and $\mathrm{n}$ is the sample size.

\section{Results and Discussion}

\section{Water Quality and Airborne Surveys Data}

Supplemental table S-1 (OR) summarizes the results of the in situ and laboratory measurements of the water quality parameters, which are representative of the water surface layer's composition at the time of sampling. According to the data, the waterbodies selected show a wide range of water compositions, from neutral to extremely acidic $\mathrm{pH}$ $(<1-7.8)$ and from low to high metal-enriched solutions (e.g. 0.04-4795.70 $\mathrm{mg} \mathrm{L}^{-1} \mathrm{Al}, 0.04-318.67 \mathrm{mg} \mathrm{L}^{-1} \mathrm{Mn}$, 0.06-2011.35 $\mathrm{mg} \mathrm{L}^{-1} \mathrm{Zn}$ ). The $\mathrm{pH}, \mathrm{EP}, \mathrm{FC}, \mathrm{FN}, \mathrm{FS}, \mathrm{SB}$, ML, TH18, LLA, LLB, and LLC were acidic $(\mathrm{pH}<1-3.8)$ while EG and EL were non-acidic (pH 6.6-7.7).

Apart from the physicochemical composition, the water bodies can be grouped based on their colors. According to some authors, the color of non-acidic waters mainly depends on the amount of organic matter, algae, suspended particulates, and nutrients (Ye et al. 2018). Thus, while EG and ML (Fig. 2) have shades of brown or green, EP and ML present greenish-blue color (Fig. 3B), and the rest of the acid water bodies have a dark reddish-brown color (Fig. 3A). The $\mathrm{Fe}^{2+}$ ions give water a greenish color and when $\mathrm{Fe}^{3+}$ ions are more abundant, they are responsible for giving the water an intense red color (Davies and Calvin 2017; Flores et al. 2021; Riaza et al. 2014; Schroeter and GläÄer 2011).

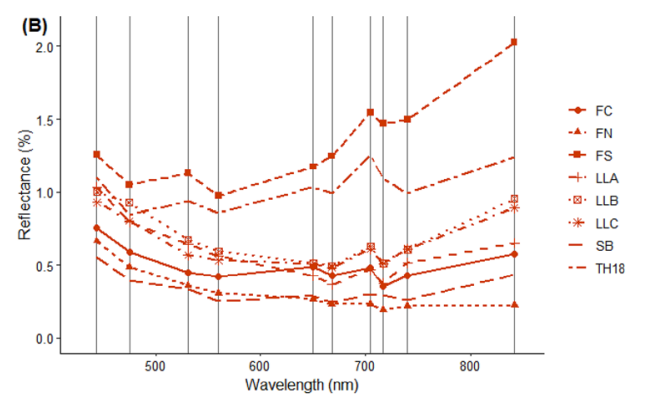

waters. Vertical gray lines indicate the spectral bands collected by the sensor at 444, 475, 531, 560, 650, 668, 705, 717, 740, and $842 \mathrm{~nm}$

Although in this study, the Fe speciation was not quantified, the ORP values around $500 \mathrm{mV}$ that were found in all of the dark reddish-brown acid waters indicate oxidized aqueous environments and the prevalence of ferric iron (Flores et al. 2021). In contrast, in the greenish-blue acidic water bodies (i.e. EP and ML), the redox potential is around $300 \mathrm{mV}$, suggesting that $\mathrm{Fe}^{2+}$ ions prevail over $\mathrm{Fe}^{3+}$. The dissolved iron composition in the dark reddish-brown acid waters was between 352.37 (TH18) and 68,940 (LLB) $\mathrm{mg} \mathrm{L}^{-1}$, while it ranged between $0.05(\mathrm{EL})$ and $0.99(\mathrm{ML}) \mathrm{mg} \mathrm{L}^{-1}$ for the rest of the water bodies.

The color difference can be observed in the spectral signatures of the water bodies shown in Fig. 4, where EG and EL (Fig. 4A) displayed higher overall reflectance in the blue-green region of the spectrum than the rest of the acid waters (Fig. 4B), with decreasing reflectance towards longer wavelengths of up to $842 \mathrm{~nm}$. In dark waters, most of the incident radiation is absorbed by the water body, and so the energy captured by the sensor decreases. For this reason, the spectral signatures of the dark reddish-brown color waterbodies have lower reflectance values over the entire analyzed spectrum. This spectral behavior can also be explained by another variable, turbidity, which is particularly important in remote sensing because it enhances the energy flux reaching the sensor due to the backscattering produced by the particles present in the water (Moore 1980; Sagan et al. 2020; Ye et al. 2018). In this sense, EG and EL were the only waterbodies that presented considerable turbidity values (8.69 and 30.35 FTU, respectively; Table S-1), ML presented 1.02 FTU, while the rest of the measured waterbodies had values near 0 FTU. In this case, the analyzed acidic waters had no significant turbidity, again decreasing the remote signal in the visible and NIR spectrum.

\section{Model Calibration and Validation}

Bands and SBCs correlation was calculated between the Micasense Rededge MX-dual data and the in situ/laboratory 
Table 2 Performance metric statistics for the best-fitted water quality parameters

\begin{tabular}{|c|c|c|c|c|c|c|}
\hline WQP & Regression & Candidate model & RMSE & RMSE\% & MAPE & Bias \\
\hline \multirow[t]{2}{*}{$\mathrm{pH}$} & SLR & $3.017-8.116 * \mathrm{~A} 1$ & 0.85 & 30 & 0.27 & 0.55 \\
\hline & MLR & 2.046-5.674*A1 + 56.413*A7 & 0.43 & 15 & 0.19 & 0.31 \\
\hline \multirow[t]{2}{*}{$\ln (\mathrm{ORP})$} & SLR & $6.397-25.657 * \mathrm{~A} 7$ & 0.22 & 4 & $\mathbf{0 . 0 3}$ & 0.16 \\
\hline & MLR & $6.265-65.699 * \mathrm{~A} 7+57.656 * \mathrm{~g} 560$ & 0.24 & 4 & 0.04 & 0.17 \\
\hline \multirow[t]{2}{*}{$\ln (\mathrm{EC})$} & SLR & $3.633-138.510 * \mathrm{~g} 531$ & $\mathbf{0 . 5 3}$ & 32 & 0.04 & 0.09 \\
\hline & SLR & $3.460-128.212 * \mathrm{~g} 560$ & 0.59 & 35 & 0.15 & 0.02 \\
\hline \multirow[t]{2}{*}{$\ln (\mathrm{Al})$} & SLR & $7.361-213.119 * \mathrm{~A} 7$ & 0.83 & 19 & 0.06 & 0.57 \\
\hline & MLR & $6.230-142.199 * \mathrm{~A} 7+6.751 * \mathrm{~A} 1$ & 0.61 & 14 & -0.04 & -0.17 \\
\hline \multirow[t]{2}{*}{$\mathrm{Ba}$} & SLR & $0.003+0.818 * g 560$ & 0.01 & 57 & 0.97 & $\mathbf{0 . 0 0}$ \\
\hline & SLR & $0.005+0.589 * \mathrm{~A} 7$ & 0.01 & 60 & 1.00 & 0.00 \\
\hline \multirow[t]{2}{*}{$\ln (\mathrm{Ca})$} & SLR & $6.223-81.167 * \mathrm{~g} 531$ & 0.59 & 12 & 0.10 & -0.11 \\
\hline & SLR & $6.142-76.486^{*} \mathrm{~g} 560$ & 0.63 & 13 & 0.10 & -0.15 \\
\hline \multirow[t]{2}{*}{$\ln (\mathrm{Cu})$} & SLR & $3.467-8.490 * \mathrm{~A} 2$ & 2.11 & 68 & 0.05 & -1.16 \\
\hline & SLR & $4.957-170.154 * \mathrm{~A} 7$ & 1.77 & 57 & 0.17 & 1.09 \\
\hline \multirow[t]{2}{*}{$\ln (\mathrm{Fe})$} & SLR & $9.489-275.345 * \mathrm{~A} 7$ & 1.38 & 25 & 0.01 & 0.75 \\
\hline & & $7.794-367.208 * \mathrm{~A} 7+597.606 * \mathrm{re} 740$ & 3.88 & 71 & 0.27 & -2.76 \\
\hline \multirow[t]{2}{*}{$\ln (\mathrm{Mg})$} & SLR & $6.606-114.772 * \mathrm{~g} 531$ & 0.71 & 14 & 0.10 & 0.13 \\
\hline & SLR & $6.448-105.262 * \mathrm{~g} 560$ & 0.72 & 14 & 0.10 & 0.07 \\
\hline \multirow[t]{2}{*}{$\ln (\mathrm{Mn})$} & SLR & $3.661-6.690 * \mathrm{~A} 2$ & 2.98 & 166 & 0.28 & -2.51 \\
\hline & SLR & $4.865-135.763 * \mathrm{~A} 7$ & 1.35 & 75 & 0.056 & -0.73 \\
\hline \multirow[t]{2}{*}{$\ln (S)$} & SLR & $9.874-181.692 * \mathrm{~g} 560$ & 1.10 & 14 & 0.09 & 0.33 \\
\hline & SLR & $9.531-130.218^{*} \mathrm{~A} 7$ & 1.08 & 14 & 0.11 & 0.36 \\
\hline \multirow[t]{2}{*}{$\ln (\mathrm{Si})$} & SLR & 4.336-99.318*A7 & 0.51 & 18 & -0.19 & 0.19 \\
\hline & MLR & $9.140-77.383 * \mathrm{~A} 7-4.872 * \mathrm{~A} 3$ & 0.76 & 27 & -0.33 & -0.65 \\
\hline \multirow[t]{2}{*}{$\ln (\mathrm{Zn})$} & SLR & 6.259-184.166*A7 & 1.33 & 40 & 0.11 & 0.22 \\
\hline & MLR & $12.536-155.498 * \mathrm{~A} 7-6.368 * \mathrm{~A} 3$ & 1.82 & 55 & 0.40 & -0.88 \\
\hline
\end{tabular}

Bold data indicates the selected model for the spatial distribution maps

$S L R$ simple linear regression, $M L R$ multiple linear regression measurements. The elements $\mathrm{K}, \mathrm{P}, \mathrm{Na}$, and $\mathrm{Sr}$ did not show a significant correlation with any spectral band, and so were discarded from the model calibration (OR Table S-2). The parameters correlated to a band or SBC with a Pearson coefficient exceeding 0.8 were used to construct different SLR and MLR models (OR Table S-3). The best two performing models of each parameter were chosen, considering that $\mathrm{R}^{2}$ and $\mathrm{Adj}^{2}$ should be close to one and SEE, AIC, and $\mathrm{p}$ value should have low values. LLC, EG, TH18, and FS flight data were used to validate the models. Among the various regression representations, the models having the best performance metric statistics were selected as the final model to predict the spatial distribution (Table 2). Additionally, Fig. 5 shows the relationship between observed and modeled values derived from the Micasense RedEdge-MX Dual multispectral imagery, confirming the robustness of the best-performing models. The high value of the coefficients of determination $\left(\mathrm{R}^{2}\right.$ between 0.81 and 0.98$)$ showed very strong relationships.

The lowest values of RMSE\% registered by the selected models $(\mathrm{RMSE} \%=4$ for $\ln (\mathrm{ORP})$ and RMSE $\%=12$ for $\ln (\mathrm{Ca})$ reflected the good predictive capability of the models. $\mathrm{Ln}(\mathrm{Al}), \ln (\mathrm{Ca})$, and $\ln (\mathrm{Mn})$ showed a tendency to underestimate the observed values (bias ranging from -0.11 to -0.73 ), while the rest of the models tended to overestimate the real values, giving a positive bias (from 0.0 to 0.75 ). Even though $\ln (\mathrm{Ca})$ showed good results in the model calibration and the validation metrics were better than other models, the graphical output showed a poor correlation between observed and modeled values $\left(\mathrm{R}^{2}=0.56\right.$ ) (Fig. 5, OR Fig. S-1). Due to the low accuracy in the prediction, $\ln (\mathrm{Ca}), \mathrm{Ba}$, and $\ln (\mathrm{Mg})$ were dismissed $\left(0.42<\mathrm{R}^{2}<0.70\right)$ (OR Fig. S1). The rest of the models presented good fitness between modeled and observed values, with $\mathrm{R}^{2}$ values between 0.81 and 0.99 , showing robust relationships between the spectral and physicochemical data. $\mathrm{Ln}(\mathrm{Si})$ had the best correlation between modeled and observed values $\left.\mathrm{R}^{2}=0.99\right)$ (SI Fig. S-1) and low RMSE\% value (18\%, Table 2).

The AMD-affected waters had a very high concentration of dissolved inorganic elements, especially Fe ions (Davies and Calvin 2017; Riaza et al. 2014; Schroeter and 

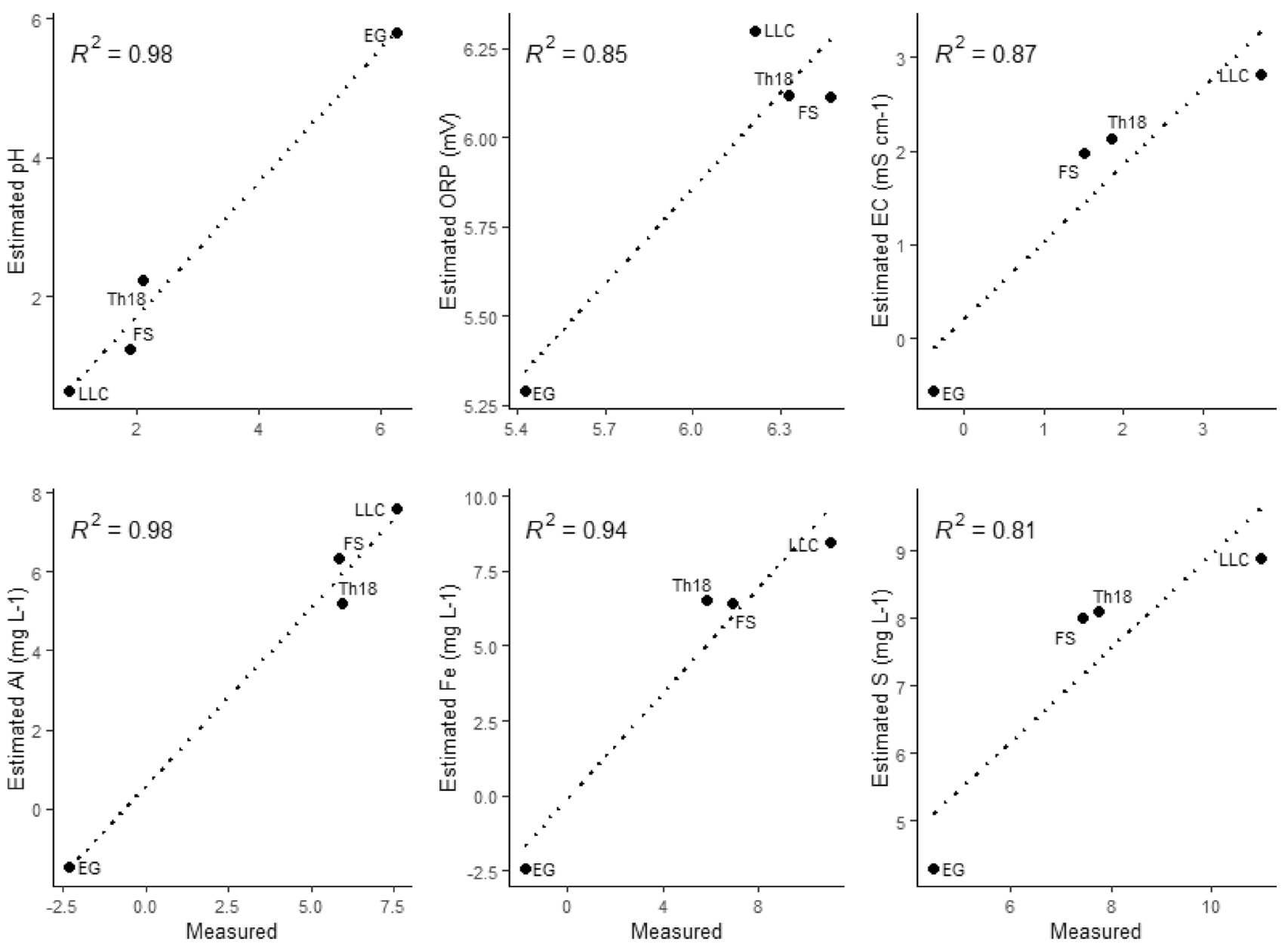

Fig. 5 Best performing models for retrieving physicochemical parameters from Micasense RedEdge-MX Dual multispectral imagery. All the models were performed with ln-transformed data, except $\mathrm{pH}$

GläÄer 2011). Fe concentrations can affect other water quality parameters, such as $\mathrm{pH}$, ORP, and EC (Davies and Calvin 2017). Previous studies have shown that the spectral region between 400 and $600 \mathrm{~nm}$ may be used to quantify $\mathrm{Fe}^{3+}$ concentration (Crowley et al. 2003; Davies and Calvin 2017). In this study, the correlation of predicted concentration values of $\ln (\mathrm{Fe})$ from remote sensing data with physicochemical data shows the highest correlation $(\mathrm{r}=-0.93)$ with the SBC A7 [(g560*g531)/b475] (Table 1), a green-blue ratio. Furthermore, the resulting regression models showed a strong association of $\mathrm{A} 7$ to $\ln (\mathrm{Fe}), \ln (\mathrm{ORP}), \ln (\mathrm{Cu}), \ln (\mathrm{Mn}), \ln (\mathrm{Si})$, and $\ln (\mathrm{Zn})$ (Table 2), indicating that these parameters are sensitive in the visible spectra. This characteristic is also true for $\ln (\mathrm{EC})$ and $\ln (\mathrm{S})$, whose models fit with the green bands g531 and g560, respectively. On the other hand, $\mathrm{pH}$ and $\ln (\mathrm{Al})$ were best estimated with $\mathrm{A} 7$ and $\mathrm{A} 1$. A1 is the NDVI index, which has previously shown a good correlation with other chemical parameters such as phosphate and turbidity (Mushtaq and Nee Lala 2017).
Few studies have quantitatively analyzed water bodies in mining environments applying remotely-sensed spectra to compare with the above findings. Schroeter and Gläßer (2011) characterized some water quality parameters in lignite mining lakes, among them $\mathrm{pH}$ and Fe. They used a bivariate correlation between Landsat TM satellite data and the chemical analysis, but no models were developed. The highest correlation was found between the red band and $\mathrm{Fe}(\mathrm{r}=0.645)$, while $\mathrm{pH}$ and the red band were poorly correlated $(r=-0.378)$. However, in the present study, the correlations found were stronger for both parameters. The $\mathrm{pH}$ was correlated with $\mathrm{r} 650(\mathrm{r}=0.765)$ but had the highest correlation with A1 $(r=-0.92)$. The Fe concentration was also correlated with $\mathrm{r} 650(\mathrm{r}=-0.66)$, having the best correlation with A7 $(\mathrm{r}=-0.93)$. Tesfamichael and Ndlovu (2018) estimated physicochemical parameters from ASTER and Landsat imagery in a gold mining area. Both satellites performed similarly in estimating Eh and $\mathrm{Ca}\left(0.25<\mathrm{R}^{2}<0.36\right.$ and $\left.19<\mathrm{RMSE} \%<56\right)$. Redox potential was estimated using the blue band (Landsat) and 

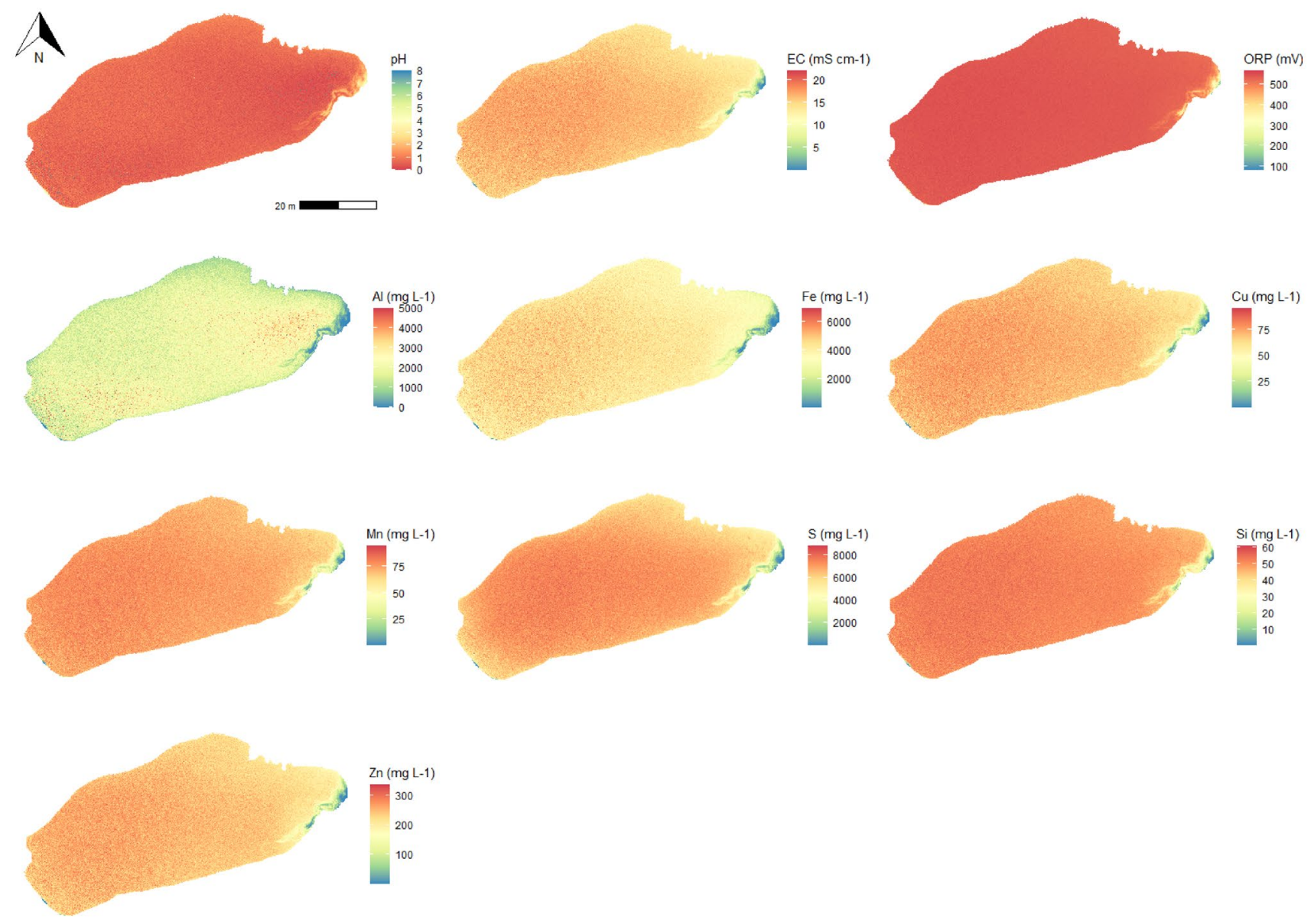

Fig. 6 Spatial distribution maps for the estimated water quality parameters in Laguna Lagunazo C (LLC), which was sampled on the 7th of October 2020

SWIR 6 (ASTER); while Ca was estimated using shortwave infrared band (Landsat) and NIR (ASTER). In this study, ORP was best estimated using A7 $\left(\mathrm{R}^{2}=0.85\right.$ and RMSE\% $=4)$ and $\ln (\mathrm{Ca})$ using g531 $\left(\mathrm{R}^{2} 0.56\right.$ and RMSE\% 12). In light of this, the models generated with UAS-multispectral imagery were different in the selected bands when compared with previous studies but the accuracy of the obtained models was higher, enhancing the value of low altitude remote sensing at a local scale.

In addition, Modiegi et al. (2020) assessed the performances of individual and combined bands of Landsat, ASTER, Sentinel 2, and SPOT 6 as predictors of water quality parameters of a river in a mining area. Results showed that Sentinel-2 and Landsat data had the best performance for most of the parameters due to their band composition, which is similar to the sensor used in this study, whose band distribution allows comparing the UAS data directly with Landsat and Sentinel images. This characteristic of the sensor provides a monitoring tool to quantify pollutants in AMD-affected water bodies at a catchment scale.

\section{Spatial Distribution Maps}

To show the real potential of UAS for monitoring acidic water and predicting water quality parameters, the empirical relationships obtained were extended to the validation dataset, producing spatial distribution maps for each studied parameter. The LLC maps are shown in Fig. 6, while the rest of them are in supplemental Fig. S-2, S-3, and S-4 (OR). The maps show that according to the physicochemical concentrations, LLC, FS, and TH18 are highly affected by AMD, while EG is a non-acidic dam. The higher values of $\mathrm{pH}$ (up to 7) were found in EG, while extremely acidic waters were found in LLC, FS, and TH18 (below 1). Furthermore, the lowest values of ORP, $\mathrm{EC}, \mathrm{Al}, \mathrm{Cu}, \mathrm{Fe}, \mathrm{Mn}$, $\mathrm{S}, \mathrm{Si}$, and $\mathrm{Zn}$ were found in EG. In contrast, LLC has the most extreme concentrations of toxic elements, which could be due to a modification in the dissolution-precipitation processes caused by the water flowing through the waste dump and the presence of pyritic ash (Sarmiento et al. 2018; Soyol-Erdene et al. 2018). In LLC, the water is stagnant and its composition is expected to be homogeneous throughout 
the water surface. Nevertheless, Fig. 6 shows that the surface water intake at the right edge has a different composition from the rest of the water body.

In FS, TH18, and EG (supplemental Fig. S-2, S-3, and $\mathrm{S}-4)$, the surface water composition data is noisy. The presence of noise is due to non-ideal environmental conditions, e.g. sunglint and wind-driven waves. The portion of downwelling irradiance that is reflected from the surface back to the atmosphere originates sunglint, which causes a variation in the spectra. Waves also modify the water reflectance by changing the line of sight from the sun to water to sensor generating glint and shadows pixels (Dekker et al. 2006; Zeng et al. 2017). Thus, these environmental conditions should be avoided in future flights.

\section{Conclusions}

The current study demonstrates that the use of empirical models to generate spatial distribution maps can be an effective and easily applicable monitoring tool in AMD-affected sites. Moreover, the commercial Micasense RedEdge-MX Dual sensor performed well in predicting several water quality parameters, which is especially valuable for small water bodies that cannot be monitored by satellites due to low spatial resolution. The results obtained here are intended to contribute to water resources management and decision-making during the exploitation and closure phase of mining sites. Once the models have been calibrated, they can be applied to new UAV surveys without the necessity for further water quality data collection, making them a more affordable and less-time consuming tool than traditional monitoring. It is noteworthy that empirical models are data-driven and are based on in situ water quality measurements (Chawla et al. 2020; Sagan et al. 2020). Thus, the models found in this study should be calibrated for application in other locations, water type, and/or season. Also, studies should be done to investigate the influence of seasonal variability on the reflectance values of the water bodies due to changes in the dissolved pollutant concentrations (Moreno González et al. 2020).

Supplementary Information The online version contains supplementary material available at https://doi.org/10.1007/s10230-021-00837-4.

Acknowledgements This study was supported in part by the Erasmus Mundus Joint Master Degree (EMJMD) in Water and Coastal Management (WACOMA) with the contribution of the Erasmus+ Programme of the European Union. This work was also supported by Plan Andaluz de Investigación RNM 166 Environmental radioactivity research group (LB). UAS equipment from University of Cádiz Drone Service supported by MINECO infrastructure projects (EQC2018-00446-P and UNCA-2013-1969). M.D. Basallote thanks the Spanish Ministry of Science and Innovation for the Postdoctoral Fellowships granted under application reference IJC2018-035056-I. The authors also thank to the editors and two anonymous reviewers for their support and comments, which notably improved the quality of the original paper.

Open Access This article is licensed under a Creative Commons Attribution 4.0 International License, which permits use, sharing, adaptation, distribution and reproduction in any medium or format, as long as you give appropriate credit to the original author(s) and the source, provide a link to the Creative Commons licence, and indicate if changes were made. The images or other third party material in this article are included in the article's Creative Commons licence, unless indicated otherwise in a credit line to the material. If material is not included in the article's Creative Commons licence and your intended use is not permitted by statutory regulation or exceeds the permitted use, you will need to obtain permission directly from the copyright holder. To view a copy of this licence, visit http://creativecommons.org/licenses/by/4.0/.

\section{References}

Abdelmalik KW (2018) Role of statistical remote sensing for inland water quality parameters prediction. Egypt J Remote Sens Space Sci 21:193-200. https://doi.org/10.1016/j.ejrs.2016.12.002

Acharya BS, Kharel G (2020) Acid mine drainage from coal mining in the United States-an overview. J Hydrol 588:125061. https:// doi.org/10.1016/j.jhydrol.2020.125061

Arango JG, Nairn RW (2020) Prediction of optical and non-optical water quality parameters in oligotrophic and eutrophic aquatic systems using a small unmanned aerial system. Drones 4:1-21. https://doi.org/10.3390/drones4010001

Barrett DC, Frazier AE (2016) Automated method for monitoring water quality using landsat imagery. Water 8:1-14. https://doi.org/10. 3390/W8060257

Bonansea M, Rodriguez MC, Pinotti L, Ferrero S (2015) Using multitemporal Landsat imagery and linear mixed models for assessing water quality parameters in Río Tercero reservoir (Argentina). Remote Sens Environ 158:28-41. https://doi.org/10.1016/j.rse. 2014.10.032

Brezonik P, Menken KD, Bauer M (2005) Landsat-based remote sensing of lake water quality characteristics, including chlorophyll and colored dissolved organic matter (CDOM). Lake Reserv Manag 21:373-382. https://doi.org/10.1080/07438140509354442

Buzzi J, Riaza A, García-Meléndez E, Weide S, Bachmann M (2014) Mapping changes in a recovering mine site with hyperspectral airborne HyMap imagery (Sotiel, SW Spain). Minerals 4:313-329. https://doi.org/10.3390/min4020313

Cánovas CR, Olías M, Macias F, Torres E, San Miguel EG, Galván L, Ayora C, Nieto JM (2016) Water acidification trends in a reservoir of the Iberian Pyrite Belt (SW Spain). Sci Total Environ 541:400-411. https://doi.org/10.1016/j.scitotenv.2015.09.070

Castro CC, Gómez JAD, Martín JD, Hinojo Sánchez BA, Cereijo Arango JL, Cheda Tuya FA, Díaz-Varela R (2020) An UAV and satellite multispectral data approach to monitor water quality in small reservoirs. Remote Sens. https://doi.org/10.3390/RS120 91514

Chawla I, Karthikeyan L, Mishra AK (2020) A review of remote sensing applications for water security: quantity, quality, and extremes. J Hydrol 585:124826. https://doi.org/10.1016/j.jhydrol.2020. 124826

Crowley JK, Williams DE, Hammarstrom JM, Piatak N, Ming CI, Mars JC (2003) Spectral reflectance properties (0.4-2.5 $\mu \mathrm{m})$ of secondary $\mathrm{Fe}$-oxide, $\mathrm{Fe}$-hydroxide, and $\mathrm{Fe}$-sulphate-hydrate minerals associated with sulphide-bearing mine wastes. Geochem Explor Environ Anal 3:219-228. https://doi.org/10.1144/1467-7873/ 03-001 
Davies GE, Calvin WM (2017) Quantifying iron concentration in local and synthetic acid mine drainage: a new technique using handheld field spectrometers. Mine Water Environ 36:299-309. https://doi. org/10.1007/s10230-016-0399-z

Dekker AG, Brando VE, Anstee JM, Pinnel N, Kutser T, Hoogenboom EJ, Peters S, Pasterkamp R, Vos R, Olbert C, Malthus TJM (2006) Imaging spectrometry of water. Imaging Spectrom. https://doi.org/ 10.1007/0-306-47578-2_11

Flores H, Lorenz S, Jackisch R, Zimmermann R, Gloaguen R, Tusa L, Contreras IC (2021) UAS-based hyperspectral environmental monitoring of acid mine drainage affected waters. Minerals 11(2):182. https://doi.org/10.3390/min 11020182

Galván L, Olías M, Cánovas CR, Sarmiento AM, Nieto JM (2016) Hydrological modeling of a watershed affected by acid mine drainage (Odiel River, SW Spain). Assessment of the pollutant contributing areas. J Hydrol 540:196-206. https://doi.org/10. 1016/j.jhydrol.2016.06.005

Gläßer C, Groth D, Frauendorf J (2011) Monitoring of hydrochemical parameters of lignite mining lakes in Central Germany using airborne hyperspectral casi-scanner data. Int J Coal Geol 86:40-53. https://doi.org/10.1016/j.coal.2011.01.007

González RM, Olías M, Macías F, Cánovas CR, Fernández de Villarán R (2018) Hydrological characterization and prediction of flood levels of acidic pit lakes in the Tharsis mines, Iberian Pyrite Belt. J Hydrol 566:807-817. https://doi.org/10.1016/j.jhydrol.2018.09. 046

Grande JA, Valente T, de la Torre ML, Santisteban M, Cerón JC, PérezOstalé E (2014) Characterization of acid mine drainage sources in the Iberian Pyrite Belt: base methodology for quantifying affected areas and for environmental management. Environ Earth Sci 71:2729-2738. https://doi.org/10.1007/s12665-013-2652-0

Hansen CH, Williams GP, Adjei Z, Barlow A, James Nelson E, Woodruff Miller A (2015) Reservoir water quality monitoring using remote sensing with seasonal models: case study of five centralUtah reservoirs. Lake Reserv Manag 31:225-240. https://doi.org/ 10.1080/10402381.2015.1065937

Japitana MV, Burce MEC (2019) A satellite-based remote sensing technique for surface water quality estimation. Eng Technol Appl Sci Res 9:3965-3970. https://doi.org/10.48084/etasr.2664

Leistel JM, Marcoux E, Thiéblemont D, Quesada C, Sánchez A, Almodóvar GR, Pascual E, Sáez R (1997) The volcanic-hosted massive sulphide deposits of the Iberian pyrite belt: review and preface to the thematic issue. Miner Depos 33:2-30. https://doi.org/10. $1007 / \mathrm{s} 001260050130$

McFeeters SK (1996) The use of the Normalized Difference Water Index (NDWI) in the delineation of open water features. Remote Sens Environ 25:687-711

Modiegi M, Rampedi IT, Tesfamichael SG (2020) Comparison of multi-source satellite data for quantifying water quality parameters in a mining environment. J Hydrol 591:125322. https://doi. org/10.1016/j.jhydrol.2020.125322

Moore GK (1980) Satellite remote sensing of water turbidity. Hydrol Sci Bull 25:407-421. https://doi.org/10.1080/026266680094919 50

Moreno González R, Cánovas CR, Olías M, Macías F (2020) Seasonal variability of extremely metal rich acid mine drainages from the Tharsis mines (SW Spain). Environ Pollut. https://doi.org/10. 1016/j.envpol.2019.113829

Mushtaq F, Nee Lala MG (2017) Remote estimation of water quality parameters of Himalayan lake (Kashmir) using Landsat 8 OLI imagery. Geocarto Int 32:274-285. https://doi.org/10.1080/10106 049.2016 .1140818

Nieto JM, Sarmiento AM, Olías M, Canovas CR, Riba I, Kalman J, Delvalls TA (2007) Acid mine drainage pollution in the Tinto and Odiel rivers (Iberian pyrite belt, SW Spain) and bioavailability of the transported metals to the Huelva Estuary. Environ Int 33:445455. https://doi.org/10.1016/j.envint.2006.11.010

Olías M, Cánovas CR, Basallote MD, Macías F, Pérez-López R, Moreno González R, Millán-Becerro R, Nieto JM (2019) Causes and impacts of a mine water spill from an acidic pit lake (Iberian Pyrite Belt). Environ Pollut 250:127-136. https://doi.org/10. 1016/j.envpol.2019.04.011

Olías M, Cánovas CR, Basallote MD (2021) Surface and groundwater quality evolution in the agrio and guadiamar rivers after the Aznalcóllar mine spill (SW Spain): lessons learned. Mine Water Environ 40:235-249. https://doi.org/10.1007/s10230-020-00713-7

Olivetti D, Roig H, Martinez JM, Borges H, Ferreira A, Casari R, Salles L, Malta E (2020) Low-cost unmanned aerial multispectral imagery for siltation monitoring in reservoirs. Remote Sens 12:1855. https://doi.org/10.3390/rs12111855

Philipson P, Kratzer S, Ben Mustapha S, Strömbeck N, Stelzer K (2016) Satellite-based water quality monitoring in Lake Vänern, Sweden. Int J Remote Sens 37:3938-3960

Pyankov SV, Maximovich NG, Khayrulina EA, Berezina OA, Shikhov AN, Abdullin RK (2021) Monitoring acid mine drainage's effects on surface water in the Kizel coal basin with Sentinel-2 satellite images. Mine Water Environ. https://doi.org/10.1007/ s10230-021-00761-7

Qian G, Li Y (2019) Acid and metalliferous drainage-a global environmental issue. J Min Mech Eng 1:1-4

Riaza A, Buzzi J, García-Meléndez E, Vázquez I, Bellido E, Carrère V, Müller A (2012) Pyrite mine waste and water mapping using Hymap and Hyperion hyperspectral data. Environ Earth Sci 66:1957-1971. https://doi.org/10.1007/s12665-011-1422-0

Riaza A, Buzzi J, García-Meléndez E, Carrère V, Sarmiento A, Müller A (2014) Monitoring acidic water in a polluted river with hyperspectral remote sensing (HyMap). Hydrol Sci J 60:1064-1077. https://doi.org/10.1080/02626667.2014.899704

Rouse JW, Space G (1978) Monitoring the vernal advancement of retrogradation of natural vegetation. In: Proc, 3rd ERTS Symp 1. pp 48-62

Runkel RL, Kimball BA, Walton-Day K, Verplanck PL, Broshears RE (2012) Evaluating remedial alternatives for an acid mine drainage stream: a model post audit. Environ Sci Technol 46:340-347. https://doi.org/10.1021/es2038504

Sagan V, Peterson KT, Maimaitijiang M, Sidike P, Sloanc J, Greeling BA, Maalouf S, Adams C (2020) Monitoring inland water quality using remote sensing: potential and limitations of spectral indices, bio-optical simulations, machine learning, and cloud computing. Earth Sci Rev 205:103187. https://doi.org/10.1016/j.earscirev. 2020.103187

Sánchez España J, Pamo EL, Santofimia E, Aduvire O, Reyes J, Barettino D (2005) Acid mine drainage in the Iberian pyrite belt (Odiel river watershed, Huelva, SW Spain): geochemistry, mineralogy and environmental implications. Appl Geochem 20:1320-1356. https://doi.org/10.1016/j.apgeochem.2005.01.011

Sanchez España J (2008) Acid mine drainage in the Iberian Pyrite Belt : an overview with special emphasis on generation mechanisms, aqueous composition and associated mineral phases. Rev La Soc Española Mineral 10:34-43

Sarmiento AM, Grande JA, Luís AT, Dávila JM, Fortes JC, Santisteban M, Curiel J, dela Torre ML, da Silva EF (2018) Negative pH values in an open-air radical environment affected by acid mine drainage. Characterization and proposal of a hydrogeochemical model. Sci Total Environ 644:1244-1253. https://doi.org/10. 1016/j.scitotenv.2018.06.381

Schroeter L, GläÄer C (2011) Analyses and monitoring of lignite mining lakes in eastern Germany with spectral signatures of Landsat TM satellite data. Int J Coal Geol 86:27-39. https://doi.org/10. 1016/j.coal.2011.01.005 
Soyol-Erdene TO, Valente T, Grande JA, de la Torre ML (2018) Mineralogical controls on mobility of rare earth elements in acid mine drainage environments. Chemosphere 205:317-327. https://doi. org/10.1016/j.chemosphere.2018.04.095

Sriwongsitanon N, Surakit K, Thianpopirug S (2011) Influence of atmospheric correction and number of sampling points on the accuracy of water clarity assessment using remote sensing application. J Hydrol 401:203-220. https://doi.org/10.1016/j.jhydrol. 2011.02.023

Su TC, Chou HT (2015) Application of multispectral sensors carried on unmanned aerial vehicle (UAV) to trophic state mapping of small reservoirs: a case study of Tain-Pu reservoir in Kinmen, Taiwan. Remote Sens 7:10078-10097. https://doi.org/10.3390/ rs70810078

Swayze GA, Smith KS, Clark RN, Sutley SJ, Pearson RM, Vance JS, Hageman PL, Briggs PH, Meier AL, Singleton MJ, Roth S (2000) Using imaging spectroscopy to map acidic mine waste. Environ Sci Technol 34:47-54. https://doi.org/10.1021/es990046w

Tesfamichael S, Ndlovu A (2018) Utility of ASTER and Landsat for quantifying hydrochemical concentrations in abandoned gold mining. Sci Total Environ 618:1560-1571. https://doi.org/10.1016/j. scitotenv.2017.09.335
Williams DJ, Bigham JM, Cravotta CA, Traina SJ, Anderson JE, Lyon JG (2002) Assessing mine drainage $\mathrm{pH}$ from the color and spectral reflectance of chemical precipitates. Appl Geochem 17:12731286. https://doi.org/10.1016/S0883-2927(02)00019-7

Yang D, Fan R, Greet C, Priest C (2020) Microfluidic screening to study acid mine drainage. Environ Sci Technol 54:14000-14006. https://doi.org/10.1021/acs.est.0c02901

Ye M, Li R, Tu W, Liao J, Pu X (2018) Quantitative evaluation method for landscape color of water with suspended sediment. Water. https://doi.org/10.3390/w10081042

Zeng C, Richardson M, King DJ (2017) The impacts of environmental variables on water reflectance measured using a lightweight unmanned aerial vehicle (UAV)-based spectrometer system. ISPRS J Photogramm Remote Sens 130:217-230. https://doi.org/ 10.1016/j.isprsjprs.2017.06.004

Zhu W, Yu Q, Tian YQ, Chen RF, Gardner GB (2011) Estimation of chromophoric dissolved organic matter in the Mississippi and Atchafalaya river plume regions using above-surface hyperspectral remote sensing. J Geophys Res Ocean. https://doi.org/10. 1029/2010JC006523 